\title{
The Rule of the Present, Not the Past
}

\author{
Franco Peirone ${ }^{1}$ (D)
}

Accepted: 13 September 2021 / Published online: 23 September 2021

(c) The Author(s) 2021

\begin{abstract}
There is a perennial ambiguity in the rule-of-law preposition: it predicates that the law shall rule, but which law? This legal loophole has led to a diverse array of interpretations of the concept. Of these, two appear particularly adverse to what the rule of law should primarily be - the rulership of the law-yet still remain dominant. On the one hand, the rule of law is intended to be the vehicle to deliver above-the-law goods such as human rights or other individual entitlements like property, and to forever shield them against any other force, including the law. On the other hand, the rule of law is believed to be a tool at the rulers' disposal, who make use of the law but are not bound by it, for either legal or practical reasons. In both cases, a pre-legal setting for society allocates rulership to something but not the law, against the very essence of the ideal: an authoritative legal practice for the sake of regulating the present society. As such, the rule of law has to meet certain requirements of craftsmanship, like conditions in law-making and law-enforcement, and sources, which are to be democratically underpinned.
\end{abstract}

Keywords Rule of law · Democracy $\cdot$ Authoritarianism $\cdot$ Legal system · Time

\section{Introduction}

There is a feeling of a trick when, reading an article which claims to deal with the preposition rule-of-law, the core of the work happens to be, more or less subtly, the respect for human rights or any other substantial good. ${ }^{1}$ At the same time, it would be unsatisfactory-even if it is a rare sight in the literature-to learn from another article that, simply, the rule of law prescribes that there shall be a law ruling, and basically the rule of law concept corresponds to the rule of any law, or the rule of the law no matter what the law is.

1 For example, Baer (2018).

Franco Peirone

franco.peirone@maastrichtuniversity.nl

1 Public Law Department, Faculty of Law, Maastricht University, Maastricht, Netherlands 
This article argues that such interpretations of the rule of law, one focused on the substantial content of the law and the other on the ruler's authorship, are not faithful to the rule of law ideal-a regulatory tool for the today's needs-, structure - to be shaped differently from other types of command - and purpose-being under the rulership of the law, and not of men - and therefore proposes an alternative interpretation of the concept. As such, it aims first to clarify the backgrounds at the basis of these two interpretations and the logical and legal conclusions they lead to; second, to explain why, as such, they are incompatible with the rule of law concept; and third, to sketch an alternative rule of law conception enshrined in democracy.

\section{Two Long-Standing but Problematic Conceptions of the Rule of Law}

The rule of law debate is particularly complex considering that, among the contemporary uncertainties present in public law, on the rule of law there is, at first glance, a widespread agreement, traversing all fault lines. The rule of law is held to be, in evaluative terms, a good thing for everyone, ${ }^{2}$ or, as has been conveniently affirmed, an unqualified human good. ${ }^{3}$ From a more practical point of view, all national governments and international organizations, from China to the $\mathrm{WTO},{ }^{4}$ from constitutional states to authoritarian regimes, praise the rule of law and predicate their activities upon it, ${ }^{5}$ based on the assumption that the rule of law is, essentially, the law in action. There is no doubt, therefore, that the rule of law is one of the most relevant values in the legal world.

Nonetheless, beyond the declaration of principle, the value currently suffers a great deal. The definition of the concept of the rule of law has been greatly narrowed by two diverging interpretations. Of course, divergent interpretations are unavoidable, especially in relation to concepts such as the rule of law, of which disputes about proper uses and contestations lie at the very core. ${ }^{6}$

However, the two dominant understandings of the rule of law seem to be far beyond mere interpretations of the concept: they are more an appropriation of the concept with a tendency to exclude any other interpretations. ${ }^{7}$

The first interpretation of the concept postulates the rule of law to not be the rule of law in general terms, but the rule of one, given, immutable law; accordingly, the rule of the law is the rule of such a law. This first interpretation has two variants, different in the content at the core of the notion but equal in structure. According to its first variant, the rule of law is conceived as the ruling of the law that protects private property and investments. Private rights then always trump the public goals and the

\footnotetext{
2 Tamanaha (2004), 1.

3 Horowitz (1977), 266.

4 Konstadinides (2017), 1.

5 Carothers (1988), 95.

6 Waldron (2002a, b), 138; Wennerström (2007), 52.

7 Gerstenberg (2019), 1054.
} 
rule of law means substantially the defence of the formers against the pretensions of the latters. This first variant has a long history with many different champions. It was the law of the English Whigs, ${ }^{8}$ and it is the one of the World Bank. ${ }^{9}$ It is the law of Locke ${ }^{10}$ and Hayek. ${ }^{11}$ It is the law of liberalism ${ }^{12}$ and-despite the fact that the continuity between the two is debated, on the rule of law they share a similar attitude $^{13}$-neo-liberalism. ${ }^{14}$ The second variant, which radically differs in the substantive values at its basis, brings however the same conclusions with regard to the structure of the concept, postulating one, superior, content-meaningful law which presides over the rule of law, in this case, human rights. The origin of such variant can be traced back to Christian scholars ${ }^{15}$ and Humanist philosophers ${ }^{16}$ who argued that, despite their different positions in this regard, the only possible human law was that which was in compliance with natural law, in either theological or rational terms. Equally, nowadays, many now hold that the law is meaningless, or invalid, if it does not comply with human rights. ${ }^{17}$ This is mostly the view of the constitutional states in the West, which hold human rights above any other law and where courts undertake extensive judicial review of legislation to this end. ${ }^{18}$

The other interpretation of the concept postulates, instead, the rule of any law insofar as it is a law. The rule of law here is simply conceived to be the command of an authority that has the decency to govern not through pure force but through the law. It has been an appealing formula in different centuries and contexts. It was the law, even if the authority at its basis and its justification greatly vary, of the Latin maxim quod princeps placuit, it habet vigorem legis, ${ }^{19}$ the droit divin on which the absolute monarchs based their power, ${ }^{20}$ and the very concrete application of the Führerprinzip. ${ }^{21}$ Therein, the form and structure of the law count little vis-à-vis the

\footnotetext{
${ }^{8}$ Mattei and Nader (2008), 12.

9 Botero and Ponce (2011), 12.

${ }^{10}$ Locke (1988).

11 Hayek (1973).

12 Van Dicey (1982).

13 Plant (2009), 46.

14 Jones (1958), 143.

15 Augustine (1950), Book IV, Chapter 4, §§ 112-113; Aquinas (2014), §§ 90-97.

16 Grotius (2005), 98.

17 Bingham (2010), 67.

18 Moyn (2012), 6.

19 Actually, the Latin legal maxim of Ulpianus (Digesta, I, 4, 1 pr.) indicated the Roman Emperor's assent was necessary to enact a law following an elaborate law-making process, which involved the Roman people and the Senate but, in practice, it was used to justify the unlimited power of the Emperor.

20 The absolute power of the Monarchs in the fifteenth to eighteenth centuries in Europe was mostly based on the doctrine of the divine right of the King, even if other tempered forms of powers were also elaborated and recognized as viable. See Bossuet (1999), 81.

21 In the National-Socialist legal thought, the Führer's will was considered to be above all laws, and all policies and decisions ought to work toward the realization of that end. See Mitchman (1996), 63. On this account, the SA Purge of 1 July 1934 could have been (retrospectively) justified through the state of emergency proclaimed on 3 July 1934, and celebrated, among others by Carl Schmitt, as the highest realization of the rule of law, on the ground of that such state of emergency suspended the ordinary course of the law and the ruler's actions instead preserved the legal system as a whole. See Vagts (2012), 205; Scheuerman (1996), 133.
} 
inherent authority of the command itself, of which the ruler is the depositary, rather than the law. Through it, the greatest interference on any individual interest, position or ambition might be done, yet it would still command the obedience of the law. Here, the content of the law is completely irrelevant to the extent that the law is simply an empty vessel in the hands of the law-makers. ${ }^{22}$ In this regard, the Marxist critique of the rule of law makes sense: the law and its rule may just be a creature of the ruling groups, even if provided with all the décor and guarantees accorded to the law. $^{23}$ It is this very type of the rule of law that is mostly prevalent in contemporary authoritarian states.

\section{A Methodological Premise and a Preliminary Punctualization}

Now that these two interpretations have been outlined, it is easy to explain why the rule of law is an object of international agreement but, at the same time, there is a deep disagreement on it, not only in practice but also, and perhaps even more, in theory. ${ }^{24}$ Both factions claim that they alone possess and uphold the rule of law and, by monopolizing it, they fail to recognize its own, independent, scientific dignity. ${ }^{25}$

In this article, it is explained why both of these conceptions of the rule of law are not faithful to its ideal, structure and purpose. The claim is that the rule of law must be neither the rule of a single given law nor the rule of any law enacted. Instead, should be the rule, in terms of forms, which respects certain parameters of law-making and law-enforcement. In terms of content-although it would be better to say with regard to its source-it should be the rule of the only law that is now accepted as legitimate, or at least upon which there is a considerable consensus in theory and practice, namely the democratic law. Such a source-in the guise of democratic credentials of the rule of law machinery-enables the rule of law to be a legitimate and effective regulatory tool for today's goals. This characterization of the concept, methodologically, does not derive from a metaphysical purview, ${ }^{26}$ but from a normative perspective. Then, the approach selected is entirely normative, and the underlying locus normative is the result of the critique of the two appropriationinterpretations of the concept of the rule of law. The investigation, then, is conceptual and not empirical: it does not aim to find out concrete examples of consensus or disagreement, or legal provisions, of and on the rule of law. Therefore, the methodology adopted is tailored to the purpose of the article: identifying how major schools

\footnotetext{
22 Gowder (2016), 14.

23 Koskenniemi (2019), 17, 18 and 27.

24 Chesterman (2008), 33.

25 The rule of law, clearly, is a legal concept. The first action that must be taken regarding a legal concept should be taking the concept itself seriously, and therefore appreciating its scientific dignity-that it is a self-standing concept-and its domaine réservé-that it has its own scope of application.

${ }^{26}$ Indeed, the law, and so its rule, is always contingent: it emerges historically. As such it is not only a contested concept, in the above definition, but also a political—determined by contextual elements-and polemical concept, used to delegitimize other competing values.
} 
of thought have investigated the rule of law, and, analysing on their reflections and pitfalls, sketching what the rule of law should mean toady.

Before entering into the details of the debate, however, one misunderstanding should be cleared up. Sustaining that the rule of law is independent from human rights-whose ideology is the primary object of criticism in this article when inextricably associated with the rule of law-does not mean that these values have nothing in common, nor does it mean that there is no merit to the studies of the rule of law that take this approach. ${ }^{27}$

It simply means that the rule of law and human rights are separate items: close enough to be a part of the same constellation, but still different stars. ${ }^{28}$ Together, they compose a political constellation that represents the common features of many legal orders, meaning that they relate to each other albeit as self-reliant, self-sustained concepts. Indeed, the fact that they may share common features and coordinate actions that may contribute to the same goal does not mean that they are the same thing, as much as, for the sake of constitutionalism, having checks and balances or free and democratic elections may contribute to the same object yet remain different legal institutions as well. By simply listing the rule of law and human rights as though they have the same rationale, nothing is achieved and much is lost: clarity in practice and effectiveness of the theory are achieved by recognizing their diversity.

\section{The Conservative Rule of Law Option}

There is a strong trend of associating the rule of law with the first interpretation/ appropriation of the concept, either in its first, liberal type or second, human rights type, and then holding it as a positive value while, in any other circumstances, it is held as a proxy for authoritarianism. ${ }^{29}$

Scholars who do so may be grouped together-even if their interpretations differ and therefore so do their guiding values (property versus human rights) - into the group of 'thick' theorists of the rule of law. ${ }^{30}$ Associating property and human rights might seem odd at first glance, but in a rule of law analysis, this is not necessarily the case: in the end, they both require the rule of law to be embedded in a substantial content (as a law entitled to rule, not a mere authoritarian command). Furthermore, historically, these two variants have overlapped. Concepts such as natural rights and the rights of men were the best argument that conservatives could find through the

\footnotetext{
27 Which mainly consists in preventing the abuse of powers linked to a positivistic conception of the (rule of) law that would allow the law-maker to achieve his goals without constraints.

28 Waldron (2014), 11.

${ }^{29}$ Both the liberal and human rights variants, as previously mentioned, share such premise, to the extent that the sub-distinction here proposed is only an internal one that relates, within a notion of rights, to those rights that are held to determine the content of the rule of law.

30 Craig (1997), 467.
} 
interwar period to support the freedom of contract and the immunity of property against social law regulation. ${ }^{31}$

Similarly, neoliberalism, at its peak, embraced and fostered the language of human rights, upholding a clear interdependence between human rights and international trade law. ${ }^{32}$ Such a 'thick' conception of the rule of law implies that, chronologically, there was a time when these superior values would have been proclaimed (or discovered, or re-discovered) and the law shall, from that moment onwards, only have the function of conserving them for the present and the future. It is evident that this is an inherently conservative-regardless of what it is supposed to conserverule of law option. ${ }^{33}$

This interpretation of the rule of law bears hidden contradictions and diminishes the value of the concept in different ways and from different perspectives. Firstly, from a theoretical standpoint, because it disregards the rule of law's normative capacity to create new legal rules or altering the existing ones. ${ }^{34}$ Secondly, from a functional standpoint, since the rule of law ideal has no bearing on the existence of spheres free from normative interference. ${ }^{35}$ Thirdly, from an ontological standpoint, since any defence of certain private legal entitlements will necessarily lead to the reduction of either collective rights or of some competing private entitlements. ${ }^{36}$ These contradictions will be discussed in next sections, taking into account different rule of law options, which thick rule of law scholars often arrange in a pyramid order.

\subsection{The 'Thick' Rule of Law Pyramid and Its Contradictions}

From the viewpoint of this interpretation of the rule of law, at the very top of the pyramid, there would be the rule of law per se, which is inseparable from the substantial content at its core, whether dealing with property/investment or human rights. In the layer just below, that comes the rule of law as elaborated by constitutional courts, which elucidates in their judgments what the rule of law is, starting from those constitutional provisions or abstract principles which shall protect such contents.

Then follows the rule of law in common law systems, based on judge made law or customary law, which, for their conservative attitude and judicial scrutiny of legislation, are the most reliable for defending those substantial contents. The final

\footnotetext{
31 Moyn (2012), 35.

32 Whyte (2019), 28.

33 The division proposed here (conservative/authoritarian), somehow overlapping the most notorious one ('thick'/'thin'), is not intended as a dichotomy, and it does not deny that mixed and moderate versions of the two interpretations (co-)exist: actually, many 'thick' theorists include in their analysis 'thin' elements and vice versa. See, for example, Beaulac (2011), 2171. Moreover, and also for these aforementioned reasons, there are still conceptions that overlook this traditional division and insist on the sociological elements of the rule of law. See Kriygier (2009), 67; King (2018), 3 and 9.

34 Palombella (2010), 37; Kryigier (2017) 38; Waldron (2012, b), 13.

35 Oakeshott (1999), 171.

36 Sempill (2016), 333.
} 
layers of the pyramid consist of the rule of law constrained by constitutions only and finally, with the pejorative name of rule by law, the rule of law made by parliaments. In this order, the latter inevitably forms a hotbed for the corruption of the law itself.

Accordingly, from a theoretical standpoint, the rule of law implies not the ruling of the law, but of something-above-the-law, usually property law or human rights law. Undetermined laws or those not referable to these superior contents are of second rank and those laws whose content is incompatible with them are not even worthy of the law's name. Aquinas' thought comes back: lex iniusta non est lex, sed corruptio legis, ${ }^{37}$ or a law that does not respect these substantial and superior contents is not a law at all. Then, the law shall-this being the rule it has to obey-only implement these contents, as a mundane tool for delivering these heavenly precepts. There is no space for the ruling of the law here: the law may uniquely be the object of the preposition rule-of-law. As such, the law shall exclusively be the servant of these values, by shielding them in the day-to-day reality. As a subject, it may exclusively be conceived of in negative terms, thereby implying that there is something else that rules, rather than the law. The law's creative function, be it for good or bad, is simply cut off: quite a paradoxical outcome, considering the original purpose of the rule of law is to have a government of laws.

Many scholars of the rule of law see the concept of law in such a negative light. ${ }^{38}$ The necessary content of the rule of law they postulate-be it property law or human rights - could be better understood, in both cases, as the security of previous individual legal entitlements against public intervention. In a society that favours the stability of the legal framework, the prospectivity and predictability of the public action alongside the protection of individual right, it ensures that anyone who has obtained a legal entitlement in the past should be protected from legislative changes in order to maximize the economic benefit or enjoyment of his/her human rights. ${ }^{39}$

From this reading, it follows that the rule of law is anchored to a precise setting of society, which, in simpler terms, might be called individualistic. It may come as no surprise, then, that, the supporters of this conception, especially of the property law variant, are sceptical not only of the public intervention, but of the democratic government at all. As synthetized by Constant, the enemy of private property rights is the public power and its rule. ${ }^{40}$ Following this line of thought, representative institutions are the acceptable lesser evil that is needed to prevent the people from using the law to obstruct individuals in their pursuit of richness. ${ }^{41}$ Similarly, theorists who assert that the rule of law is grounded in human rights embrace democracy; however, they believe that it should be limited in order to prevent popular decisions from having an impact on human rights. These are respectable positions, but they

\footnotetext{
37 Aquinas (2014), § 31 .

38 Cass (2004), 131.

39 Buchanan (1975), 17.

${ }^{40}$ Constant (1988), 12. Constant particularly believed that the ancient conception of liberty, from ancient Athens for example, was mainly a public conception of collective liberty and its implication was the limitations of individual freedoms, and particularly the right to pursue the richness that he thought, in the end, would have prevailed vis-à-vis the government.

41 Demonstenes (1926), § 127.
} 
are misguided when they assume that the rule of law is automatically on their side. Both variants of the rule of law privilege, inevitably, the individual, as an economic operator or human being, over the community, whose interests the law represents.

Also, this kind of understanding of the rule of law favours and is favoured by the development of legal frameworks that protect these legal entitlements, no matter where and when they were enacted. This is the aim, for example, of international investment law, which establishes its own courts and enacts its own body of law, alongside picturing the traditional public law restrictions on the individual right to property (expropriation) as a violation of the rule of law. ${ }^{42}$ This is the case of the international human rights regime too, which sets up its own system of courts and rights and has the tendency to describe any human rights limitation enacted at the national level as a violation of the rule of law. ${ }^{43}$ Both of these legal frameworks resort then to the rule of law concept and appeal. International investment law and international human rights do not just affirm that alleged violations to those entitlements are such (infringements of property and human rights respectively), but also that they invoke a greater value, on which there is a larger agreement, like the rule of law, for protecting them.

The underlying assumption of this rule of law perspective is, therefore, a sceptical, diffident and generally negative attitude vis-à-vis public power. Differently from anarchism and even more subtly, certain neo-liberal theories, ${ }^{44}$ the rule of law tradition-and this is commonly accepted in the academic discourse-does not seek to eliminate public power. However, 'thick' rule of law theorists infer that the rule of law serves as a safeguard over the government, which it is, and that the rule of law means having a limited government, particularly exempting property law and human rights from government intervention, which it is not. The function of the rule of law is not to protect specific individual entitlements from public power: instead, it is to protect different legal entitlements, both public and private, from the arbitrariness of public and private powers. ${ }^{45}$ Private power may indeed be a risk to public needs and this is a rule of law concern, just as much as the exploitation of public power poses a threat to private legal entitlements. The rule of law is about the building and shaping of such powers, public and private ones, and to check the capacity of them to interfere each other. ${ }^{46}$

In actuality, with specific regard to the relationship with public power, the rule of law's function is not simply limited to acting as a check against public power, but instead, to refine it through a series of requirements and procedures. ${ }^{47}$ It is then, at the same time, a coessential element of public power, which might be used to limit or to expand the reach of its action. At the same time, it is a completion element, which by providing structure, discipline and form to the public power, renders it

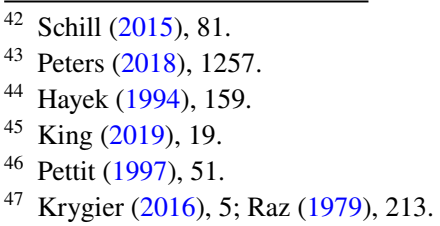


more effective and intelligent. The terms 'controlling' 48 and 'tempering, ${ }^{49}$ are particularly fitting for explaining these characteristics of the rule of law in the quest to determine its function. 'Controlling' the government means that it is possible to either limit or expand the government power. Control is not a purely negative concept: it can also refer to an affirmative response to the controller's will, as the rule of law does.'Tempering' power does not make it less effective; as much as tempering steel makes is stronger and fitter, by tempering power, the rule of law exploits and enhances the legal characteristics. ${ }^{50}$

Besides, 'thick' rule of law theorists support the rule of constitutional law, mainly as interpreted by constitutional courts.$^{51}$ However, from a theoretical point of view, there is no reason to inextricably associate the rule of law with constitutional mythology, based on superhuman framers of constitutions whose rule-as dead men-is much more noble and wiser than the rule of living men. Constitutionalism itself has other purposes than the rule of law, so not every aspect of constitutionalism concerns the rule of law, and not everything that comprises the rule of law is a constitutional matter. While constitutions typically focus on the content of laws, the rule of law limits itself to a matter of forms and source. 'Thick' rule of law theorists would again disagree, then providing no autonomous relevance to the concept of the rule of law. ${ }^{52}$ Constitutionalism appears, when it is perpetual and of a negative type of constitutionalism only, ${ }^{53}$ to be a constraint to the rule of law. ${ }^{54}$ A constraint that is needed in any society-no one wants an exclusively democratic rule of law society - but which should advise more prudence when equating the rule of law with constitutionalism. ${ }^{55}$ This also applies to constitutional law as interpreted by constitutional courts. No constitutional court can act insofar as to dismantle any legitimate law without literally breaking the rule of law itself. Judicial review of legislation, when of a strong type assigning to judicial bodies the task of law-making, ${ }^{56}$ disrespects the core of the rule of law. ${ }^{57}$ No rule of law is possible if the law is forever ossified, be it by a source of law that constitutionalizes and shields everything in the world, in terms of over-constitutionalization, or by a body of men and women who perpetuate this vision in terms of originalism.

The same could be said of the (quite mythological) common law version of the rule of law that, generally, thick theorists cherish. ${ }^{58}$ From a structural point of view, common law provides judgments of an ad hoc character, with opacity, generally unpredictable and inherently retroactive, all characteristics that the rule of law

\footnotetext{
48 Waldron (2012a, b), 17.

49 Kryigier (2017), 34; Holmes (2012), 192; Mann (1988), 32.

50 Braithwaite (2019), 277; Cheesman and Janse (2019), 255; King (2019), 36.

51 Scheppele (2018), 545.

52 Krygier (2017), 35.

53 Rubenfeld (2001), 46 and 128.

54 Brodie (2014), 252.

55 Raz (1979), 214.

56 Waldron (2002a, b)(b), 181.

57 Waldron (2021), 105; Waldron (2006a), 1346.

58 Hayek (1973), 118.
} 
should be inimical to. ${ }^{59}$ Even rule of law scholars who model their theories on an unlegislated system cannot be comfortable with it. Sure enough the neoliberals, and their equivalents in human rights activism, want something more than this. It is the functional perspective, which makes common law so attractive to them. They actually want to avoid any legislation that hampers the status quo and, in doing so, strip the ruling of the law of the title of rule of law, and consign it exclusively to the legal protection of what has been previously settled, by custom, power or market.

This vision inherently relies on the judicial function, as the inherent habitat of the law and of the rule of law, because it is in front of the court that the individual defends his or her legal entitlement against the pretensions of public power, or at least this is the case in a certain common law mythology. ${ }^{60}$ A certain fascination with the whole common law world has brought to understand the concept of the rule of law through the prism of that world. ${ }^{61}$

This had led to an almost schizophrenic attitude regarding the concept of the rule of law to the extent that it is frequently interpreted against the very meaning of the concept: the rule of law, in the end, means that someone should concretely rule and that 'someone' is the law. ${ }^{62}$

\footnotetext{
59 It is interesting to note that common law, at least in its most orthodox or mythological interpretations, does not comply at all with the rule of law requirements and guarantees: according to Bentham, the law that is derived from court judgments could not at all be said to be general (since it is centered around a single case) transparent (because nobody knows how and why judges decide in a certain way), constant (since a different court may decide differently a similar case) and prospective (being necessarily focused on facts already happened before the judgment itself) to the extent that he nicknamed it 'dog law.' Then, while it is theoretically possible that the common-law judges of the past had the super-human gift of providing judgments with perfect substantial content, and then achieving justice for society, for sure their outputs were not laws. See, in particular, Bentham (1970), § 101.

${ }^{60}$ Hayek (1973), 72 and 122.

${ }^{61}$ It is an open debate whether discussing the rule of law means also dealing with the questions of law authority and its claim to be obeyed. The understandings of the rule of law and of the concept of law seem to the author of this article much more closely connected than they generally are in the current discussion over the rule of law, where instead it is preferred to divide such issues, arguing that one thing is discussing the rule of law and another one is discussing the authority of the law. Authors who do so, especially the 'thick' rule of law theorists, treat the rule of law as rather a mysterious ideal, whose own underlying values are quite unrelated to the understanding of the law itself and instead neglect the question of the authority of the law. Actually, by following this approach, which clearly distinguishes the rule of law topic and the authority of the law topic, they fall in the most of the positivistic pitfalls, coming to the conclusion that the (rule of) law rules because it is the law. On the contrary, in this article, it is claimed that the rule of law as a normative ideal arises out of the understanding of what law is. The rule of law represents then a natural trajectory of normative thought arising from the normative significance of law's defining features. The rule of law, then, is a complex phrase and the word law is one of its founding components. Grammar itself indicates that it is needed to understand the concept of law before understanding the one of the rule of law, as the concept of law is part of the greater concept of the rule of law. Now, considering that the rule of law means that something or someone shall rule and that something or someone is the law, it is untenable to not have an understanding of what the law is and why it has authority. See Waldron (2009), 4.

${ }^{62}$ Customary and common law could be backgrounds that justify this theory. Sometimes they are invoked; in other cases they are simply a 'guise' for those in power, or sometimes it is simply the Benthiam Judges \& Co. See Postema (1986), 267.
} 


\subsection{Rescuing the Law in the Rule}

Actually, it is precisely the last option, the rule of law made by parliaments, so often condemned by the supporters of the first interpretation, that represents the evident habitat of the rule of law. The rule of law mostly means a dependence on the law as adopted by parliaments: in the common conception of the separation of public powers, the executive and judicial branches must not only act in compliance with the law made by parliaments but they are also bound in a stricter sense as they must not act at all unless authorized to do so by such law. ${ }^{63}$ Law made by parliaments therefore has a dominant role that is owed to its institutional nature, being that it is an institution that has been established and is explicitly dedicated to drafting and altering the law alongside procedural features, which are also known as virtues of legislation, which focus on the public, transparent and dialectic features of the enactment of laws in parliament. ${ }^{64}$

The rule of law is then, first and foremost, the rule of law made by parliaments: it is an ideal for human institutions and not a trick for depriving human legislators of their right to rule. ${ }^{65}$ However, this simple assumption has been dispelled by a number of scholars, who hold that everyone who supports legislation in the rule of law supports autocrats, and that a 'thin' rule of law - a rule of law that does not (have to) comply with those aforementioned values - is nothing more than rule by law, which is the best scenario that civil law countries and legislative states may attain.

Coherently, 'thick' rule of law theorists minimize the rule of law by legislation and legislation as main source in any legal system. ${ }^{66}$ Their implied positions are easy to detect. For example, the World Bank Justice Project has a 'Rule of Law Index' dependent on national risk for international investors: the question of which law rules, is easily answered: the rule of investment law. ${ }^{67}$ Similarly, the supporters of the human rights conception of the rule of law find the normative ground for obedience to the law in the human good the law pursues. Adherence to the rule of law, instead, should be predicated on what the law is, and not what it is used for (enforcing this or that right), and thus autonomously from any instrumental conception of the law. ${ }^{68}$

The rule of law entails a particular dimension of allegiance to the law, even when disagreement occurs on the goal the law aims to achieve. ${ }^{69} \mathrm{~A}$ 'thin' conception of the rule of law, then, is a source of autonomous respect that sustains this allegiance as such, depending on the formal legal requirements. ${ }^{70}$ It is expected to comply with the law that meets such formal requirements, even if there is disagreement about

\footnotetext{
63 Merli (2016), 41.

64 Waldron (2015); Gardbaum (2018).

65 Waldron (2006b), 15.

66 Barro (2000).

67 World Bank, World Justice Project Rule of Law Index, at https://worldjusticeproject.org/our-work/ research-and-data/wjp-rule-law-index-2020 last visited on 30 August 2021.

68 Goodpaster (2003), 686.

69 Fuller (1958), 630.

70 Waldron (1994), 275.
} 
what it should provide. ${ }^{71}$ Laws that satisfy those requirements have, for that reason, a claim to allegiance that is independent from their substantive aspirations: the duty of obedience cannot depend on any individual assessment of any substantive reasons to follow the law. ${ }^{72}$ This actually reflects reality rather well: the majority of the laws that humanity obeys and makes use of have nothing to do with human rights.

Instead, the academic debate on the rule of law continues to adopt this attitude; most of the attention goes to the limits of the rule of law rather than to its function. The debate therefore revolves around ideas like the inviolability of human rights; the prohibition of retroactivity; the requirements of foreseeability, generality and so on. Of the two pillars of the rule of law, that people should obey the law and that the law should be such that people will obey it, the latter has become predominant.

This approach has reduced the rule of law's normative capacity to the sole purpose of shielding the established legal entitlements of citizens. ${ }^{73}$

\subsection{Ruling Through Swords and Shields}

The old metaphor of the rule of law being a shield and not a sword, ingenuous though it may be, actually reveals this contradiction. This metaphor is meaningless in its open, apodictic significance: that the law should protect citizens like a shield and not offend them as a sword might.

Against this stance, one may raise not only the most obvious of objections: that a legal order also has the necessity to punish, sanction and impede, through criminal and administrative laws for instance. More generally, in fact, any defence of a certain legal entitlement necessarily leads to the reduction of certain competing entitlements: what is a shield for someone might almost necessarily be a sword against

\footnotetext{
71 As Ronald Dworkin highlights, it is common to prove repugnance, lose fidelity and deny authority to the law when it has got a 'checkerboard' form, such as, for example, a statute making abortion illegal for women born in even years but not for those born in odd years, regardless of what we think about the substantial issue at stake, in this case abortion. Dworkin (1986), 166.

72 Helmich (2020), 263; Waldron (2003), 45; Raz (1986), 35.

73 The idea comes from James Madison who argued that the priority was to enable the government to control the governed, and in the next place oblige it to control itself (Madison, 1961, 347). Joseph Raz also highlighted that the concept of the rule of law has two basic aspects: that people should be ruled by the law and obey it and that the law should be such that people will be able to be guided by it (Raz, 1979, 213). However, on the first pillar, he himself does not elaborate and takes it for granted but leaving, inevitably, a blank spot. Also, Lon Fuller admits that the very first kind of failure of the rule of law is the failure to achieve rules at all and make them respected (Fuller, 1969, 39). The actual problem of compliance with the law is often avoided by the 'thick' rule of law theorists, subtly but coherently with their thesis: since public intervention is mostly a threat to private rights or human rights, and since the rule of law is the proper tool for limiting such intervention, the least amount of public intervention is best for these underlying values and for the rule of law itself. Therefore, the actual compliance with the rules and their enforcement-also because of the separation thesis between the rule of law and the law authority, see supra note 57-are not topics very often touched upon in rule of law analyses. Compliance with the law, law-enforcement, sanctions and deliberate public actions are instead definitive features of the rule of law. Their prominence may vary from system to system, but their presence is indispensable to the notion of the rule of law.
} 
someone else. ${ }^{74}$ However, this metaphor has a deeper, darker, ideological, meaning that explains its success. It is not meant to sustain the rule of law as such-because it would be, as before explained, meaningless-but a particular version of the rule of law. It is a particular purview according to which the law shall only protect what individuals already have, and not because of the law, which is merely a servant, but due to a pre-normative asset. ${ }^{75}$

The rule of law protects only some goods and only some individuals, who have already been provided with those goods. ${ }^{76}$ The rule of law as a shield is just the defence of a particular status quo. ${ }^{77}$ It imbues the rule of law with an intrinsically conservative character. It is, therefore, uniquely a (politically conservative) variant of the rule of law. Actually if one truly follows this interpretation of the rule of law, one must accept a series of implausible and unsustainable premises and consequences. First, that the framers of the original order were super-humans (or divine entities), always and forever better than any law-makers, and whose rules were so wise that they shall not only never be reverted, but that would not even have to be adapted or altered to fit any new circumstances. Second, that the law is inherently stupid and that a 'super-law' — such as a constitutional law or a constitutional court judicial activity, or a pre-normative asset-is necessary at any time in any case, or, otherwise, it must be accepted that many fields of law cannot be governed by the principles of the rule of law. Third, that the rule of law only serves to prohibit certain public actions - against property and human rights for example - and never to perform any of them-such as providing services or goods. Fourth, that a global Paretian optimum-which shall regard all of the many aspects the law takes into account: justice, but also economy, morality, sustainability etc.- - has been reached once and for all in a day of blazing glory for humanity, which the rule of law must crystalize. Fifth, that no social or technological change should be fostered, accepted or considered by the law, since it would imperil the societal setting that has then been reached. Sixth, that this rule of law, and this alone, is generally good in its content for all the peoples around the world, and if not, they are simply hostages of authoritarian regimes, or, at best, of rule by law states.

It has been said that it is not the rule of law's mission to foster social and political change, since this is also the task of other principles such as the social state and citizen participation. ${ }^{78}$ However, at the same time, it is not the rule of law's mission either to prevent such transformations, or to be framed in order to make them impossible. In actuality, social and political change is not embedded in the rule of law concept itself, but rather is its possible and unavoidable long-term output once established that the rule of law has something to do with democracy.

74 Selznick (2016), 25.

75 Cass (2004), 83.

76 Bentham (1931), 119.

77 Mattei and Nader (2008), 197.

78 Schroeder (2016), 22. 


\section{The Authoritarian Rule by Law Option}

This reasoning against a 'thick' version of the rule of law, its premises and ideological background, directed towards dismantling its partisan interpretations, does not necessarily mean subscribing to the second, equally partisan, interpretation of the same concept. The rule of law shall not be the rule of that law only, nor can it even be the rule of any law. In particular, it cannot be the rule of anyone in power merely because they have the power. The rule of law's theoretical aspects cannot in fact be conciliated with a total positivistic approach to the law, that the law is an empty vessel-which, still, is not coincident with the exercise of brute power-subject to the sole and ultimate will of the legislator. While a legislator's will may have the force to command, it does not automatically amount to the rule of the law: in the paradigmatic division, it is simply the rule of men. Nonetheless, history has been marked by the limitless number of regimes that claimed to possess, adhere to and implement the rule of law by simply following the law their rulers had commanded ${ }^{79}$; and of jurists who, in good or bad faith, have reconstructed their commands not only as being legitimate and necessary, but even as authentic expressions of the rule of law. ${ }^{80}$

Before moving on to the argumentation regarding (and testifying against) any authoritarian interpretations of the rule of law, a disclaimer is necessary. Classifying all authoritarian regimes in the same way in regard to the rule of law is a mistake. They vary considerably in their level of adherence to the rule of law and, as such, also having a rule by law system might be considered a significant achievement.

\subsection{Lights and Shadows of the Authoritarian Rule of Law}

As said before, 'thick' rule of law scholars are quick to judge countries that do not enact their conception of the rule of law as being endowed with rule by law. However, even the term rule by law, conveniently described as a much more maligned proposition, ${ }^{81}$ should be firstly analysed, since its contrast with the 'good twin,' the rule of law, may appear misplaced.

Rule by law is almost always associated with the use of law as a tool or instrument to serve the ends of those in power in an authoritarian regime, to the extent that rule by law and authoritarian regimes are considered synonymous.In its darkest version, rule by law means the state uses law to control its citizens but never allows law to be used by the citizens to control the state. It is clear that in the rule by law, the law is ruling but it is not being ruled, while, ideally, in the rule of law, the law is both ruling and ruled. Now, if the rule by law entails that the authority is wholly

\footnotetext{
79 Picking up a contemporary (and now influential) example, the Chinese understanding of the rule of law is mainly about following the law duly delivered by the rulers. See $\mathrm{Li}$ (2000).

${ }^{80}$ Hobbes (1991); Austin, (1995); Schmitt (1985).

81 Waldron (2019), 1.
} 
unconstrained in the measures it lays down, this is not compatible with the rule of law and deserves the title of being an authoritarian system. ${ }^{82}$

Nonetheless, even the rule by law state admits something more than a mere use of brute power: the Hobbesian state - the rule by law archetype where the law-maker is not bound to the law he enacts ${ }^{83}$ - is already something highly different from the arbitrary form of government, despotic governments or the law of the jungle. In these latter instances, the law and legal procedures, wherever they may exist, are used selectively in an arbitrary and inconsistent manner in order to make political suppression and social control more effective, something which rule by law regimes do not necessarily do.

Hobbes instead believed that law-makers should not be limited by rules in the drafting of laws in order for progress to be made and to avoid any possible fear of society, and the state framework as the result of the preceding argumentative steps of the state of nature and the social contract which creates the particular Hobbesian relationship between ruler and ruled. ${ }^{84}$ Therefore, the law regulates the relationship, which is unbalanced between the government and the governed, although it is not arbitrary. Here, the rule by law is not a simple apology of the brute command of the men in power but something like a formal discipline of legality. ${ }^{85}$ Rule by law is different from ruling by mere force or command also by a procedural point of view: the laboriosity, publicity and dialectic of the process are generally different. Moreover, the acts they adopt usually match the requirements of the rule of law to be general, clear, prospective, public and relatively stable. Then, the laws, once adopted, are usually coherently enforced. This ensures stability, predictability and many other requirements of the rule of law. Again being ruled by law is not entirely a scenario of failure.

\subsection{The Limit of the Rule by Law}

Rule by law is then valuable to the extent that it implies that rulers do in fact accept notions like the formal discipline of legality. Rule by law represents an attempt to rule the world through rules, even if it is not worthy of the name rule of law. Therefore, how does rule by law, like the paradigmatic Hobbesian scenario, differ from rule of law and, if (not) doing so, how does it fail? There could be numerous different types of rule by law regimes and any one of them may fail when it comes to one or more rule of law requirements. Typically, it is the result of a structural defect: the rule of law binds the ruled but not the ruler who, instead, is an absolute sovereign, meaning unconstrained by the rule of the laws they enact. ${ }^{86}$

This has been, historically, the situation of the absolute states of the Modern Age and, from a logical point of view, the conclusion to which Hobbes came; that is, in

82 Sellers (2014), 13.

83 Waldron (2013), 439; Waldron (2019), 3.

84 Hobbes (1991), 1651.

85 Straumann (2019), 1126.

86 Frankenberg (2019), 19. 
order to rule effectively, the sovereign must have absolute power. Nowadays, rule by law is still an option in many states whenever the rulers are shielded unreasonably much and unlimitedly by legal provisions that have shielded them through the application of the laws they have enacted. Structural defects in the law-making are evident in the enactment of ad personam laws, which are clearly directed at guaranteeing the ruler's personal interests rather than ensuring any public good. Ad personam laws might be of two different types; some may be clearly framed in such a way that the persons concerned and the interest ensured could only have been the ruler and their own assets. For example, the law might seek to provide the rulers with immunity from prosecution by the law, explicitly referring to them or, more subtly, to the public office they hold. It is clear that, even in the second instance, only the current ruler would benefit from the adoption of the law-being the ruler at that time- and that law is exclusively made for their own personal purposes-since the need for such immunity had never been presumed to be compelling before. ${ }^{87}$

Other ad personam laws may be enacted with a general scope of application, and in principle serve a general purpose but de facto, on account of timing and circumstances, serve only, or mostly, the ruler's interests. For example, no one can deny that more lenient punishments for certain crimes could possibly be of general interest. However, it would be difficult not to see the rulers' interest prevailing over any considerations when, for example, the reformed legislation concerned crimes that they themselves have been accused of.

Another failure of an authoritarian state in regard to the rule of law is whenever the application of the law eliminates or threatens the equality between the rulers and the ruled. It is common in authoritarian states that the law is not equally enforced on the ruler, even if this should theoretically be possible. By extension, this shielding may also encompass their family, friends, party affiliates and other selected groups. The executive and judiciary functions are practically constrained from their rule of law duties to enforce and adjudicate according to the law. In these circumstances, the law may still exist, while there is no longer an unchallenged rule of law: instead, there is a rule of men, who may make use or non-use of the law, or abusing it. ${ }^{88}$ For these reasons, corruption is usually held to be an anathema to the rule of law because it substitutes the rule of law as a matter of behaviour orientation and dispute resolution. It may be added that corruption as a criminal activity flourishes exactly in regimes that violate the rule of law, even if the evidence is not one-sided here. ${ }^{89}$ In such cases, following the rule of law instead means giving full effect to its 'preemptive' or 'exclusionary', authority. ${ }^{90}$

A rule of law system then differs from a rule by law system as it relies on the generality of the law_as a rule of law requirement of the law-making - and in impersonality in the application of the law_as a rule of law requirement of the lawenforcement: the law is not aimed at anyone in particular but generally at anyone

\footnotetext{
87 Rose-Ackerman (2014), 5.

88 Rose-Ackerman (2004), 14.

89 Warren (2004), 328.

90 Raz (2006), 126.
} 
who satisfies the requirements that trigger the law; and once those requirements have been triggered, the law has to be applied regardless of any other consideration. ${ }^{91}$

\subsection{Reaching the Public Good Through the Rule of Law}

Therefore, when the law bounds both the rulers and the ruled alike, both theoretically and practically, it is a very different scenario. ${ }^{92}$ This is because this bond is of legal significance, as Fuller exemplified in his $8^{\text {th }}$ requirement of the rule of law list: there needs to be congruence between what a written statute declares and how officials enforce those statutes. ${ }^{93}$ Also, Rawls agreed that having an impartial and consistent administration of law is an essential element of the rule of law, ${ }^{94}$ and Finnis too, who claimed that the law generally and presumptively commands people and institutions to comply with it. ${ }^{95}$ Founded on this equivalence between rulers and the ruled in respect to the law and the congruence between what predicated and what enforced, is the duty to obey the law.

The only content limitation is that the law must pursue the public good ${ }^{96}$ and not the ruler's private interests, as occurs with ad personam laws, either explicitly or implicitly, or in any other use, non-use or abuse of the law. ${ }^{97}$ This limit of the public good, even if difficult to detect, prevents the instrumentalization of the rule of law for authoritarian temptations. Here, it is important not to fall for the false dilemma between a too rigid natural law interpretation and a too crude positivist one. Instead of saying that nothing is law unless it promotes the public good, it might be said to that nothing is law unless it purports to promote the public good, which means unless it presents itself as oriented in that direction. And the public good, in current public law thought, may be determined and reached only through democracy. ${ }^{98}$

Here lies the rule of law's legitimacy: it cannot claim to be legitimate unless it is conditioned by and then expresses an a priori community under equality between the rulers and ruled: in a word, democracy. This leads to the fact that in claiming legitimacy for itself, the rule of law puts an end-goal as its basis: it is the public

\footnotetext{
91 Sunstein (1994), 27.

92 Kryigier (2009), 67.

93 Fuller (1969), 39.

94 Rawls (1972), 58.

95 Finnis (1980), 270.

96 The public good is transcendent, per definition, the self-interest of the powerful. It is then against the concept of the rule of law to apply it to norms that address matters of personal or partial concern or institutions that make no pretense to operate in the name of the whole community, orienting themselves instead to the benefit of the individuals who control them. See Waldron (2009), 36.

97 In this limited sense, it is possible to speak of a tyranny of the majority through the law, in its most intense form, because the decisional actor-one individual invested with the power of law-makingcoincides with the topical actor-one given individual again, who is the only recipient of the message of the law. Ad personam laws might be called non-core cases of the rule of law. See Waldron (2006a, b), 1401 .

98 Rubin (1989), 369.
} 
good of the legal order which is the end-goal of its authority and is determined by democracy. ${ }^{99}$

Then, the public good it is essentially of a temporary nature, because democracy always allows, and perhaps even fosters, the changing of rulers, and then the changing of the community's end-goal. ${ }^{100}$ Surely, having the end-goals subjected to change and having pursued it through the rule of law may allow for brutal and unjust consequences to occur, such as genocide, suppression and so on. ${ }^{101}$ In a word, plunder. But the reaction against these undesired outcomes of the law-from both the social engineering and legitimization points of view-is that it is still the law, and not the use of a substantial notion, which always coincides with an economic and political dominant landscape. ${ }^{102}$

There must be a different conception of the rule of law that is more faithful to its ideal, structure and purpose, and which does not fall into the conservative temptations of the 'thick' conception nor allows for the authoritarian usurpations linked to a purely positivist rule of law option. This is another theory of the rule of law which allows the content of the law to be changed, thus enabling the current 'losers' to uphold the system and search for a better future where they might be the 'winners ${ }^{103}$ : this is the rule of law in a democracy. ${ }^{104}$

\section{A Democratic Rule of Law Conception}

The conception here proposed is surely a 'thin' theory of the rule of law-meaning that the structures which assess its rule of law likeness do not regard the content of the law-which places a particular emphasis on the conception and source of the law, and particularly, on democratic legislation. The rule of law should then comply with certain requirements so that the will of the rulers will be constrained, but these requirements do not regard its content but rather the source, the making and enforcement of the law. There, and only there, where no other requirements are imposed on the definition, it could be legitimately said that there is the rule of the law, and not of something else.

\section{1 'Thin' Credentials of the Democratic Rule of Law}

It is odd to start with the two latter requirements but, for analytical purposes, it is more convenient, since there is a certain agreement that the rule of law should contain them. The lists of requirements vary between different authors who have faced this issue: just to mention the most well-known list, the law must be sufficiently

\footnotetext{
99 Cohen (2010).

100 Waldron (1996), 2185.

101 Alexy (1999), 17.

102 Oakeshott (1999), 178.

103 Waldron (1999), 6.

104 Habermas (2001), 43.
} 
general, publicly promulgated, prospective, clear and intelligible, free of contradictions, relatively constant, possible to obey, and administered in a way that does not wildly diverge from their obvious or apparent meaning. ${ }^{105}$ Such key principles concern the law-making and law-enforcement altogether.

This specification is necessary because the functions of law-making and lawenforcement are clearly distinguishable in any legal system: creating the law is one thing, applying it is another thing entirely. With regard to the issues dealing with rule of law, law-making and the enforcement of the law are at the same time identical yet distinct. The matter at hand always seems to be compliance with the rule of law. However, the former concerns how the law is made, what the law openly affirms; the second, instead, regards how the law is enforced, such as what its implementation is for society. Certain rule of law requirements, such as fair administration and the prohibition of arbitrariness, are directly linked to the executive function of the rule of law, which has its own, distinct dignity. After all, the rule of law is not simply about writing good laws: well-drafted laws should match impartial application and coherent enforcement.

This means that the rule of law does not only imply institutional structures to the handling of the power-how the law should be framed-but also to the effectiveness of its rule, that the law should be enforced. ${ }^{106}$ As mentioned previously, the law entitled to rule needs to be sufficiently general, publicly promulgated, prospective, minimally clear and intelligible, free of contradictions, and relatively constant: these are requirements which clearly concern the fabric of the law, the law-making. Once these requirements have been satisfied, the law has to be enforced impartially and fairly. ${ }^{107}$ It may then be argued that the rule of law does not permit the non-enforcement of decisions.

Without fair enforcement and the prohibition of arbitrariness, considering that arbitrariness also includes non-application of relevant law, ${ }^{108}$ the rule of law is incomplete. ${ }^{109}$ The rule of law is then incompatible with the arbitrary exercise of authority since it is actually what it aims to prevent, but authority itself is quintessential to the rule of law, to its ruling component.The requirements of law-making and law-enforcement apply then to all of a state's activities. Accordingly, the legislative branch has to draft the rules and publish them in a prospective, consistent, stable and understandable manner, while the executive branch has to apply these rules in an impartial and accountable manner, thereby avoiding the pursuit of its own goals outside the legal framework and enforcing the legal entitlements as provided by the law. ${ }^{110}$ People in positions of authority should exercise their power within a constraining framework of public norms rather than on the basis of their

\footnotetext{
105 Fuller (1969); Marmor (2004); Waldron (2012, b); Waldron (2011); Waldron (2009).

106 Krygier (2017); Waldron (2013).

107 Merli (2016), 39; Krygier (2012), 240; Shklar (1998), 44.

108 Corrales (2015); Radin (1989).

109 Tòth (2017), 402.

110 Finnis (1980), 270; Fuller (1969), 39.
} 
own preferences, their own ideology, or their own individual sense of right and wrong. ${ }^{111}$ The judicial branch is required instead to oversee the legislative and executive branches' activities, and to challenge the laws and the regulations. There must then be an independent judiciary, proving a forum where the law may be challenged following procedural rules such as open and fair hearings and the absence of bias. At the same time, since the courts are a part of public power, their judicial power must also comply with the rule of law: extensive judicial power requires extensive scrutiny and the expectation of compliance with the rule of law. The consequence of compliance with the rule of law of all these three components will make the law rule as such, and thus makes a rule of law order. ${ }^{112}$

\subsection{Obedience to Each Own Law}

With regard to the third, and perhaps more contested, element, the rule of law source, this article argues that the rule of law, in order to be sustainable, must be democratic or, more generally, must allow for changes in both law-makers and the contents of the laws being enacted. As discussed previously, the rule of law requires obedience to the law, in the name of the law's authority. But this authority would be intolerable if it were perpetual in the content of its command. It would forever perpetuate one and only one worldview and command towards all the members of its legal order, be it the content of superior values, as in the conservative rule of law option, or the will of the ruling people, as in the authoritarian rule of law version. Once these precepts are combined with the proposition of the rule of law, the ruling of the law becomes difficult to sustain. Both of these interpretations of the rule of law, despite being at the antipodes, favour stability. Stability might be a good thing for the law but when it turns into immutability, it is not.

In actuality, immutability is an inherent characteristic of the conservative conception of the rule of law-more than the authoritarian one, which at most favours the immutability of the law-makers-because the substantial values the rule of law protects are ontological to its existence, or even its own justification. Both these conceptions of the rule of law are therefore intolerable from the legitimization point of view and unfaithful to the rule of law ideal and purposes. The rule of law should be an intelligent tool for regulating today's society's needs and goals, and for ensuring that the law made by today's men rules, rather than the law made in the past, or simply the pure will of today's rulers. Truly, in a democracy, the norms that citizens are ruled by could be content-wise different. It is only a human decision to have

111 Waldron (2009), 5.

112 The independence of each function (legislative, executive and judiciary) means that the ruling of the law is uncompromised from its inception in the legislative branch, through its application by the executive one and to its review by the judicial one. In each of these branches, there are of course influencing human factors, and factors external to the law (How close is the law-maker to the industrial complex? Are the law-enforcers educated enough in legal matters? What the judge had for breakfast?), but in a rule of law order they all are minimized as much as possible. 
them and keep them as a basis for legal interactions that explains why these norms are law and not some others. Those who are ruled by these laws understand they are ruled in a rule of law system that is susceptible to alteration, and that might be done by changing the law-makers, whose task is also to deliberately alter the society and having its own rule subject to change. The rule of law has therefore no claim to any absolute rigidity of the legal framework. An acquired right to consistency of case law or law does not exist, and the legislature must, at least generally, not be prevented from amending the law. ${ }^{113}$

That said, there is rarely a year zero for legislation. The overwhelming majorities of the laws are kept despite the change of law-makers, because of the continuity in a political community that recognizes itself as one. Therefore, most laws are consistent also with the desiderata of the changing majorities within the same community. When instead there is a clear change in one direction, the temporal scope of the law applies: new regulations derogate from previous rules, generally, without retroactive effects, because there is usually no need to undo what has been done since, what has then been repealed had a collective meaningful purpose and strived for the public good.

This idea of law therefore conveys an elementary sense of self-determination, a sense in which a community is free to have whatever laws it likes: the laws that govern it could be subject to change. A demand that the law should be different may be impracticable from a political point of view, but it is not analytically futile, as it would be in the case of natural law or the law of the market. It is instead inherent to the democratic legal system that the law can be altered from time to time, and indeed it should be altered when needed. ${ }^{114}$ Indeed, law-making is an art and change may be necessary once and again, in this as in any other art, vis- $a$ vis old customs which may become exceedingly simple, useless or barbaric over time. ${ }^{115}$ This positive and democratic attitude towards change was, at the end, the very essence of Aristotle rule of law revolution ${ }^{116}$ against the customary, tribal and traditional values of the oligarchical clans, the àgrapta nòmima ${ }^{117}$ —a kind of 'thick' conception of the rule of law-as well as against any type of authoritarian form of government cultivated by wise men by virtue of their superior judgments, as his mentor Plato envisaged. ${ }^{118}$

\footnotetext{
${ }^{113}$ Legislation as a deliberated alteration of a society rules is the essence of the rule of law. A law that can only act as a safeguard of customs is not a rule of law option. Not because of the content-goal itself, since the law may obviously favour and enact conservative intervention legitimately, but because the law and its content have to be subject to change too. Here, presumably, is where what I label the conservative conception of the rule of law fails at most: for the thinkers who endorse such option, the rule of law means the rule of property law and morality, and both of them are timeless, God-given, unchallenged and unchallengeable. See Waldron (2004), 319.

${ }^{114}$ Popelier (2008), 51.

115 Oakeshott (2006), 244; Aristotle (1995), Book II, Ch. 8.

116 Aristotle (1995), Book III.

117 Sophocles (1947), §§ 450-457.

118 Plato (1995), 57.
} 


\subsection{Democratic Functioning and Ruling of the Law}

Following this assumption, it would still be problematic if that meant simply the protection of the values of the men of today instead of yesterday, and it is still dubious which grounds justify obedience to the laws that enact those values.

Yet, if the precepts of the law were modifiable by the same subjects of the legal order, they would comply with the law even if, at that particular moment, it did not match their values. The rule of law thus requires legal order where the law-makers and the law-abiders not only obey the same rules, which is the line of separation between rule of law and rule by law, but are actually the same, and equal before the law. ${ }^{119}$

Democracy, then - as a continuous process of changing the people in poweris the only possible ground for bearing the rule of the law, because the people are the law-makers, ${ }^{120}$ or they could be in the future, since not all the people can be law-makers at the same time, but only a majority, as resulting from the democratic process. ${ }^{121}$ Hence, the condition of ruler or ruled is accidental, and intrinsically, temporary. The rule of law requires then that rulers treat the ruled as if the latter could rule the former: not in the name of morality, but because it is the very concrete functioning of democracy. ${ }^{122}$ The rulers do not need then to make sure that the content of every decision is acceptable to all subjects to whom it applies-this would be impossible_-but, more modestly, that they themselves must be ready to accept opposite decisions.

In this continuum ruling-and-being-ruled within a regime of equal, effective control over the state, the command of the law is not the imposition of an alien will: it is self-ruling. ${ }^{123}$ This is why Aristotle's inquiry into the dyad of ruling-and-beingruled ('to know the rule of free people from both sides') is the culminating point of his reasoning about democracy and how it differs from despotism. ${ }^{124}$ This account of identity has been a constant element of the relationship between the (rule of) law and democracy. ${ }^{125}$ Still, this is not a 'thick' element in the rule of law, as much as

\footnotetext{
119 Lindhal (2015), 62.

120 Aristotle (1995), Book III, Ch. 1.

121 Issacharoff (2013); Frank (2005).

122 Howse (2019), 656.

123 Pettit (1997).

124 Aristotle (1995), Book III, Ch. 4, § 1277a (20).

125 The idea has not been limited to the ancient Greece civilization and the socio-political context of a single polis, like Athens, where a regime of direct democracy was in force. Within the communitarian, but not democratic, legal framework of the medieval Europe, Aquinas distinguished between despotic and political regimes, whereby the free are governed, exactly by describing the latters as having authorities governing over citizens who are ontologically equal to the rulers (Aquinas (2014), §§ II). Later, in the limited democratic setting of the Constitution of USA, Tocqueville, who surely favoured a liberal understanding of the law and a conservative representative democracy, still endorsed the same idea in his illustration of the democratic functioning, by holding that a democratic legislation gives ordinary people a voice, by involving them in the enactment of the law, and does so on the basis of political equality (De Tocqueville (2012), 244). In current times, and in the context of constitutional democratic states, Habermas has pointed out that the rule of law requires that those subject to the law as its addressees can, at the same time, understand themselves to be authors of the law (Habermas (1996), 121).
} 
the activity of the ruling and the existence of a law cannot be considered as such. It is an ontological, but not metaphysical, requirement of the rule of law, which makes the rule of law legitimate and acceptable because enshrined within the functioning of democracy. Law is therefore authoritative not because it expresses values that are ontologically valid for everyone and forever, ${ }^{126}$ but because it is continuously and constantly validated by the democratic process. ${ }^{127}$ But again, not all laws have these authoritative credentials, only those laws that respect certain requirements in legitimacy and craftsmanship. The former is satisfied by the democratic source, and the latter by the aforementioned requirements in law-making and law-enforcement. It is true that the rule of law and democracy are not the same, but democratic law as a means to pursue the public good is the only possible way to uphold democracy and the rule of law together. ${ }^{128}$ The rule of law's demand for obedience to the law is impossible if the law in question does not stem from a democratic system. ${ }^{129}$ The law commands obedience because, between equals who are all subject to the same laws, now and in the future, it can return obedience. At the same time, the rule of law is needed to shape the popular will into a functioning legal system. ${ }^{130}$ All of this makes democracy the only true ally of the rule of law.

\section{Conclusions}

This article aimed to explain that, while the rule of law is considered to be an unqualified human good on which there is an international agreement, in concreto it is supported by legal strands which employ it as a means to their ends, whether debatable or not, of substantive immutable values on the one hand and of power grabbing and exercising on the other. ${ }^{131}$ Such interpretations-appropriations of the concept do not respect its own theoretical premises and expectations, while establishing a bond between the functioning of democracy and the ruling of law gives to the latter an acceptable meaning. Indeed, full acceptance of the implications of the rule of law may only come about in conjunction with radical democracy, where the constraint of obedience is coessential to the commonality between law-makers and law-abiders, and the law has a proactive function of achieving the public good.

\footnotetext{
126 Böckenförde (2017), 157.

127 Cappelletti, Seccombe and Weiler (1986), 47.

128 The resulting element of achievement of the public good derives, then, from the enforcement of what has been decided, avoiding drafting and enforcement of check board statues. See Dworkin (1986), 179.

129 Democratic law exerts then a tremendous normative pull, not because it rests on some substantial content, but because it expresses the will of the sovereign people. In a democratic regime, the citizens themselves are sovereign. It is here that rule of law and democracy are linked: the sovereign people govern through the rule of law; and by obeying to the rule of law, citizens participate in popular sovereignty and achieve democratic self-government (Haltern (2021), 231).

130 Weiler (2004), 547.

131 Actually, the rule of law has been the banner of liberal and neo-liberal regimes on the one hand (for example, the UK in the eighteenth and nineteenth centuries, and the USA in the twentieth and twentyfirst centuries), and of authoritarian regimes on the other (for example Germany during the National Socialist regime and the People's Republic of China currently).
} 
One may argue that other values might suffer in radical democratic states, which is true. ${ }^{132}$ However, they vindicate a habitat for the rule of law, which flourishes alongside democracy, where law-makers and law-abiders are the same. ${ }^{133}$

The rule of law is an anathema to the rule of men: but men will always be present in this world and there will always be men, be they the many or the few, behind the rule. Still, having the law as a medium between men and their goals, and granting it alone the capacity to rule, as described in this article, enables the men self-rule, as identification between the rulers and the ruled.The rule of law is meant then to be the antidote to the rule of those men who want to keep the status quo forever and ever and of those who do not want to be constrained by the rule they themselves impose; it is a response to the rule of status and to absolutism. The law, and its rule, should be separate from both the immutable tradition of the past and from the command of today's powerful men.

Open Access This article is licensed under a Creative Commons Attribution 4.0 International License, which permits use, sharing, adaptation, distribution and reproduction in any medium or format, as long as you give appropriate credit to the original author(s) and the source, provide a link to the Creative Commons licence, and indicate if changes were made. The images or other third party material in this article are included in the article's Creative Commons licence, unless indicated otherwise in a credit line to the material. If material is not included in the article's Creative Commons licence and your intended use is not permitted by statutory regulation or exceeds the permitted use, you will need to obtain permission directly from the copyright holder. To view a copy of this licence, visit http://creativecommons.org/licen ses/by/4.0/.

\section{References}

Alexy R (1999) A defence of Radbruch's formula. In: Dyzenhaus D (ed) Recrafting the rule of law. The limits of legal order. Bloomsbury/Hart, Oxford, pp 15-39

Aquinas (2014) Summa theologica. B McGinn (Tr.) Princeton University Press, Princeton

Aristotle (1995) Politics. E Baker (Tr.) Oxford University Press, Oxford

Augustine (1950) The City of God. Modern Library, New York

Austin J (1995) The province of jurisprudence determined. W. Rumble (Ed.) Cambridge University Press, Cambridge

Baer S (2018) The rule of-and not by any-law. On Constitutionalism. Curr Legal Problems 71:335-368

Barro R (2000) Democracy and the Rule of Law. In: De Mesquita B, Root H (eds) Governing for Prosperity. Yale University Press, Yale, pp 209-232

Beaulac S (2011) The rule of law, international law and interlegality: what heuristic model (thin, thick or 'à la Carte'). Revue de la recherche juridique - Cahiers de méthodologie juridique 24:2171-2184

Bentham J (1931) The Theory of Legislation. In: Ogden C (ed) Paul, Trench, Trubner \& Co., London Bentham J (1970) Of laws in general. In: HLA Hart (Ed.) Athlone Press, London

\footnotetext{
132 It has been the case of the democratic Athens of the fifth century B.C.; see Grote (2010) Vol. XII, Ch. 5; Mitford (2011) Vol. V, Ch. 21; and of Jacobin France of the Revolutionary period; see Palmer (1960), 448; Woloch (1970), 92. The analysis of these historical examples by the purview of the rule of law-and their concrete consistency with such ideal-are beyond the scope of contribution, but they prove concrete implementation of the idea that the rule of law normative locus is democracy, and that the juncture between the rule of law and human rights, on the one hand, or the rule of law and authoritarianism, on the other hand, is not unavoidable.

133 Habermas (1996); Ober (2008); West (2011).
} 
Bingham T (2010) The rule of law. Allen Lane, London

Böckenförde EW (2017) The historical evolution and changes in the meaning of the constitution. In: Kunkler MM (ed) Ernst-Wolfgang Böckenförde, Constitutional and political theory. Selected writings. Oxford University Press, Oxford, pp 152-168

Botero AM, Ponce JA (2011) WJP Rule of Law Index. The World Justice Project, Washington D.C.

Bossuet J B (1999) Politics drawn from the very words of holy scripture. Riley P (Ed) Cambridge University Press, Cambridge

Braithwaite J (2019) Tempering Martin. Hague J Rule Law 11(2-3):277-281

Brodie J (2014) New constitutionalism, neo-liberalism and social policy. In: Gill S, Cutler E (eds) New constitutionalism and world order. Cambridge University Press, Cambridge, pp 247-260

Buchanan JM (1975) The limits of liberty: between anarchy and Leviathan. University of Chicago Press, Chicago

Cappelletti M, Seccombe M, Weiler JHH (1986) Methods, tools, and institutions, integration through law: Europe and the American federal experience. De Gruyter, Berlin

Carothers T (1988) The rule of law revival. Foreign Affairs March/April: 95-106

Cass R (2004) Property rights systems and the rule of law. In: Colombatto E (ed) The Elgar companion to the economics of property right. Edward Elgar Publications, Cheltenham, pp 131-158

Cheesman N, Janse R (2019) Martin Krygier's passion for the rule of law (and his virtues). Hague J Rule Law 11(2-3):255-276

Chesterman S (2008) An international rule of law? Am J Comp Law 56(2):331-361

Cohen J (2010) Rosseau: a free community of equals. Oxford University Press, Oxford

Constant B (1988) Liberties of ancients compared with that of the moderns. Fontana B (Tr.) Cambridge University Press, Cambridge

Corrales J (2015) Autocratic legalism in Venezuela. J Democr 26:38-45

Craig P (1997) Formal and substantive conceptions of the rule of law: an analytical framework. Public Law $467-488$

De Tocqueville A (2012) Democracy in America. Schleifer JT (Tr.) Liberty Fund, Indianapolis

Demonstenes (1926) Against Leptines C.A. Vince CA (Tr.) Harvard University Press, Harvard

Dworkin R (1986) Law's empire. Cambridge University Press, Cambridge

Finley MI (1987) The ancient Greeks. Penguin Editions, London

Finnis J (1980) Natural law and natural rights. Oxford University Press, Oxford

Frank J (2005) A democracy of distinction. Aristotle and the work of politics. University of Chicago Press, Chicago

Frankenberg G (2019) Authoritarian constitutionalism - coming to terms with modernity's nightmares. In: Garcia HA, Frankenberg G (eds) Authoritarian constitutionalism. Comparative analysis and critique. Edward Elgar, Cheltenham

Fuller L (1958) Positivism and fidelity to law - a reply to Professor Hart. Harv Law Rev 71:630-672

Fuller L (1969) The morality of law: revised edition. Yale University Press, Yale

Gardbaum S (2018) Due process of lawmaking revisited. UCLA Public Law Res Pap 18(12):1-32

Gerstenberg O (2019) Radical democracy and the rule of law: reflections on J. Habermas' legal philosophy'. Int J Const Law 17(4):1054-1058

Goodpaster G (2003) Law reform in developing countries. Transnational Law Contemporary Problems 13:659-698

Gowder P (2016) The rule of law in the real world. Cambridge University Press, Cambridge

Grote G (2010) History of Greece. Cambridge University Press, Cambridge

Grotius (2005) The rights of war and peace. Tuck R (Ed.) Liberty Fund, Indianapolis

Habermas J (1996) Between facts and norms. Rehg W (Tr.) MIT Press, Cambridge

Habermas J (2001) The post-national constellation. MIT Press, Cambridge

Hayek F (1973) Law, legislation and liberty. University of Chicago Press, Chicago

Hayek F (1994) The road to serfdom. University of Chicago Press, Chicago

Haltern U (2021) Revolutions, real contradictions, and the method of resolving them: the relationship between the Court of Justice of the European Union and the German Federal Constitutional Court. Int J Const Law 19(1):208-240

Harrington J (1992) The commonwealth of Oceana and a system of politics. Pocock GCA (Ed.) Cambridge University Press, Cambridge

Helmich M (2020) Spain, Catalonia, and the supposed authority of the judiciary on the self-constitutive moment in adjudication. Jus Cogens 2:259-279

Hobbes T (1991) Leviathan. Tuck R (Ed.) Cambridge University Press, Cambridge 
Holmes S (2012) Passions and constraints. In: Rosenfeld M, Sajo A (eds) The Oxford handbook of comparative constitutional law. Oxford University Press, Oxford, pp 192-218

Horowitz MJ (1977) The rule of law: an unqualified human good? Yale Law J 86(3):561-566

Howse R (2019) Epilogue: In defense of disruptive democracy-a critique of anti-populism. Int J Const Law 1:641-660

Issacharoff S (2013) The democratic risk for democratic constitution. Const Court Rev 5:31-58

Jones HW (1958) The rule of law and the welfare states. Columbia Law Rev 58(2):143-156

King J (2018) The social dimension of the rule of law. Int J Const Law Blog, April 27, 2018

King J (2019) Martin Krygier and the tempering of power. Hague J Rule Law 11(2-3):363-370

Konstadinides T (2017) The rule of law in the European Union. Hart Publishing, Oxford

Koskenniemi M (2019) EJIL foreword: Imagining the rule of law: rereading the Grotian "Tradition." Eur J Int Law 30(1):17-52

Kriygier M (2009) The rule of law: legality, teleology, sociology. In: Palombella G, Walker N (eds) Relocating the rule of law. Hart Publishing, Oxford, pp 67-81

Krygier M (2012) Rule of law. In: Rosenfeld M, Sajò A (eds) The Oxford handbook of comparative constitutional law. Oxford University Press, Oxford, pp 240-269

Krygier M (2016) The rule of law: pasts, presents and two possible futures. Annu Rev Law Soc Sci 12:199-229

Kryigier M (2017) Tempering power. In: Adams M, Ballin EH, Meuwese A (eds) Bridging idealism and realism in constitutionalism and rule of law. Cambridge University Press, Cambridge, pp 34-69

Krygier M (2017) Why the rule of law matters. Jurisprudence 9(1):146-158

Lane Scheppele K (2018) Autocratic legalism. Univ Chicago Law Rev 85:545-583

Li LC (2000) The "Rule of Law" policy in Guangdong: continuity or departure? Meaning, significance and processes. China Quarterly 161:199-220

Lindhal H (2015) Law as concrete order. In: Dyzenhaus D, Poole T (eds) Law, liberty and the state. Cambridge University Press, Cambridge, pp 38-63

Locke J (1988) Two treatises of government. P Laslett (Ed.) Cambridge University Press, Cambridge

Madison J (1961), The federalist 347-429. Cooke JE (Ed.) Wesleyan, Connecticut

Mann M (1988) State, war and capitalism. Blackwell, London

Marmor A (2004) The rule of law and its limits. Law Philos 23(1):1-43

Mattei E, Nader L (2008) Plunder: when the rule of law is illegal. Blackwell Publishing, Hoboken

Merli F (2016) Principle of legality and hierarchy of norms. In: Schroeder W (ed) Strengthening the rule of law in Europe: from a common concept to mechanisms of implementation. Hart Publishing, Oxford, pp 22-39

Mitford W (2011) History of Greece. Cambridge University Press, Cambridge

Mitchman SW (1996) Why Hitler? The Genesis of the Nazi Reich. Praeger, Westport

Moyn S (2012) The last utopia. Harvard University Press, Harvard

Oakeshott M (1999) The rule of law. In: Oakeshott M (ed) On history and other essays. Liberty Fund, Indianapolis, pp 129-179

Oakeshott M (2006) Lectures in history of political thought. O’Sullivan L (Ed.) Inprint Academic, Upton Pyne

Ober J (2008) The original meaning of "Democracy": capacity to do things, not majority rule. Princeton/ Stanford Working Paper in Classic Paper n. 090704

Palmer RR (1960) Popular democracy in the French Revolution. Fr Hist Stud 1(4):445-469

Palombella G (2010) The rule of law as institutional ideal. In: Morlino L, Palombella G (eds) Rule of law and democracy. Brill, London, pp 3-38

Peters A (2018) Corruption as a violation of international human rights. Eur J Int Law 29(4):1251-1287

Pettit P (1997) Republicanism: a theory of freedom and government. Oxford University Press, Oxford

Plant R (2009) The neo-liberal state. Oxford University Press, Oxford

Plato (1995) The statesman. Waterfield R, Julia Annas J (Tr.) Cambridge University Press, Cambridge

Popelier P (2008) Five paradoxes on legal certainty and the lawmaker. Legisprudence 2(1):47-66

Postema GJ (1986) Bentham and the common law tradition. Oxford University Press, Oxford

Radin MJ (1989) Reconsidering the rule of law. Boston Univ Law Rev 69:785-786

Rawls J (1972) A theory of justice. Oxford University Press, Oxford

Raz J (1986) The morality of freedom. Clarendon Press, Oxford

Raz J (1979) The authority of law. Oxford University Press, Oxford

Raz J (2006) The problem of authority: revisiting the service conception. Between authority and interpretation: on the theory of law and practical reason. University Press, Oxford, pp 126-165 
Rose-Ackerman S (2014) Corruption and conflicts of interest. In: Auby J-B, Breen E, Perroud T (eds) Corruption and conflicts of interest. A comparative law approach. Edward Elgar Publishing, Cheltenham, pp 3-14

Rose-Ackerman R (2004) Corruption and government: causes, consequences, and reform. Cambridge University Press, Cambridge

Rubin EL (1989) Law and legislation in the administrative state. Columbia Law Rev 89:369-426

Rubenfeld J (2001) Freedom and time: a theory of constitutional self-government. Yale University Press, Yale, p 128

Scheuerman W Ed (1996) The rule of law under siege. Selected essays of Franz L. Neumann and Otto Kirchheimer. University of California Press

Schill SW (2015) International investment law and the rule of law. In: Lowell J, Thomas JC, Van Zyl SJ (eds) The importance of the rule of law in promoting development. Academy Publishing, Singapore, pp $81-102$

Schmitt C (2008) Constitutional theory. J Selitzer (Tr.) Duke University Press, Duke

Schmitt C (1985) The crisis of parliamentary democracy. Kennedy E (Tr.) MIT Press, Cambridge

Schroeder W (2016) The EU and the rule of law. In: Schroeder W (ed) The European Union and the rule of law-state of affairs and ways of strengthening. Hart Publishing, London, pp 3-22

Sellers M (2014) What is the rule of law and why is it so important. In: Silkenat JR, Hickey JE, Barenboim PD (eds) The legal doctrines of the rule of law and the legal state (Rechtsstaat). Springer Verlag, Berlin, pp 3-13

Selznick P (2016) Legal cultures and the rule of law. In: Krygier M (ed) The rule of law after communism. Routledge, London, pp 25-59

Sempill J (2016) Ruler's sword, citizen's shield. J Law Politics 31:333

Shklar J (1998) Political theory and the rule of law. Chicago University Press, Chicago

Sophocles (1947) Antigonis. Watling EF (Tr.) Penguin Books, London

Straumann B (2019) The rule of law: sociology or normative theory? An afterword to Martti Koskenniemi's foreword. Eur J Int Law 30(4):1121-1127

Sunstein C (1994) Rules and rulesness. Coase-Sandor Institute Working Paper No. 27

Tamanaha B (2004) On the rule of law: history, politics, theory. Cambridge University Press, Cambridge

Tòth GA (2017) Illiberal rule of law? Changing features of Hungarian constitutionalism. In: Adams M, Ballin EH, Anne Meuwese A (eds) Constitutionalism and the rule of law: bridging idealism and realism. Cambridge University Press, Cambridge, pp 386-416

Van Dicey A (1982) Introduction to the study of the law of the constitution. McMillan and Co., London

Vagts D (2012) Carl Schmitt's ultimate emergency: the night of the long knives. Ger Rev 87:203-209

Waldron J (1994) Why law - efficacy, freedom, or fidelity? Law Philos 13:275

Waldron J (1996) Legislation, authority, and voting. Georgetown Law J 84(6):2185-2214

Waldron J (1999) Law as disagreement. Oxford University Press, Oxford

Waldron J (2002a) Is the rule of law an essentially contested concept (In Florida)? Law Philos 21(2):137-164

Waldron J (2002b) Judicial power and popular sovereignty. In: Mark A, Graber MA, Perhac M (eds) Marbury versus Madison: documents and commentary. Sage Publications Gallery, New York, pp 181-220

Waldron J (2003) Authority for officials. In: Meyer LH, Paulson SH, Pogge TW (eds) Rights, culture and the law: themes from the legal and political philosophy of Joseph Raz. Oxford University Press, Oxford, pp 45-61

Waldron J (2004) The rule of law as a theater of debate. In: Burley J (ed) Dworkin and his critics. WileyBlackwell, Hoboken, pp 319-336

Waldron J (2006a) The core of the case against judicial review. Yale Univ Law J 1(115):1346-1406

Waldron J (2006b) Principles of legislation. In: Bauman R, Kahana T (eds) The least examined branch: the role of legislatures in the constitutional state. Cambridge University Press, Cambridge, pp 15-32

Waldron J (2009) The concept and the rule of law. Georgia Law Rev 43:1-61

Waldron J (2011) The rule of law and the importance of procedure. In: Fleming J (ed) Getting to the rule of law. New York University Press, New York, pp 3-31

Waldron J (2012a) The rule of law and the measure of property. Cambridge University Press, Cambridge

Waldron J (2012b) Constitutionalism: a skeptical view. NYU School of Law Public Law Research Paper No. 10-87, 17

Waldron J (2013) Separation of powers in thought and practice. Boston Coll Law Rev 54(2):433-467

Waldron J (2014) The rule of law in public law. Cambridge Public Companion, Cambridge

Waldron J (2015) Legislation and the rule of law. Legisprudence 1(1):91-123 
Waldron J (2019) Rule by law: a much maligned preposition. Public Law Research Paper NYU School of Law, No. 19-2019

Waldron J (2021) The rule of law and the role of courts. Glob Const 10(1):91-105

Warren ME (2004) What does corruption mean in a democracy? Am J Pol Sci 48(2):328-343

Watts A (1993) The international rule of law. German Yearbook of International Law 36:15-45

Weiler JHH (2004) The geology of international law - governance, democracy and legitimacy. Zeitschrift Für Ausländisches Öffentliches Recht Und Völkerrecht 64:547-562

Wennerström EO (2007) The rule of law and the European Union. Iustus Förlag, Uppsala

West R (2011) The limits of process. In: Fleming J (ed) Getting to the rule of law. New York University Press, New York, pp 32-51

Whyte J (2019) The morals of the market: human rights and the rise of neoliberalism. Verso, New York Woloch I (1970) Jacobin legacy: the democratic movement under the directory. Princeton University Press, Princeton

Publisher's Note Springer Nature remains neutral with regard to jurisdictional claims in published maps and institutional affiliations. 